\title{
Hidden Casualties: Burma, Siam (Thailand), and the Philippines in World War Two History and Film
}

\author{
Rick Derrah
}

\begin{abstract}
This paper examines the World War Two in Burma, Siam (Thailand), and the Philippines and the reflection of that history within films produced during the same time period. War films were produced all three of these countries during the war period, but, in general, focus almost exclusively on American or British characters as the heroes. There is also very little content dealing with the casualties suffered by the indigenous populations of these countries during the war.
\end{abstract}

Keywords: History; World War Two; Film

\section{INTRODUCTION}

In society popular culture often shapes the perception of the past. These views of the past are sometimes adjusted to make the story more appealing to the projected audience and with the advent of movies this phenomenon has only accelerated. Theses views build upon and reinforce each other creating constructs which are widely known. Movies are often able to create their own reality by building on these common constructs. The view of the movie becomes the reality for many people and this is problematic because movies and other forms of popular culture are created with agendas beyond simply telling a story. These hidden agendas can be simply the story the version of the story the creator wishes to express or even the motivation to make the work profitable. This phenomenon is can be observed in the large pool of movies centered on the Second World War.

Even a quick look at films about the Second World War will show a large group centered on the early stages of the war in the Pacific. Recently on the $60^{\text {th }}$ anniversary of the bombing of Pearl Harbor Hollywood produced a new version of that attack featuring Ben Affleck. This trend can be following right back to the movies produced during the war. Many of these films center on a common group of elements including: the rapid advance of the Japanese in the early war period and the bravery of those who opposed this advance. One element which seems to be neglected in these stories of the conflict in the Southeast Asian theater both in the written and the film media is the discussion of the incredible toll inflicted on the people of the Philippines, Burma, and Thailand. By looking at the history of the early war period and some films based on this time period it is easy to see the almost total lack of any discussion of impact on the people native to this area. These films create a reality were these people become hidden casualties.

\section{EARLY VICTORIES}

By May 1942 Japan had made rapid and unexpected advances in South East Asia and captured large amounts of territory. In just six months the Japanese had achieved all their objectives with very few casualties in men and in material in comparison to the allies. They had managed to cut the Burma Road separating China from her source of support. The Japanese had also managed to fight the perception of American and European invincibility and remove many of their former colonies from their influence and place them under Japanese control. "The new empire was truly vast, stretching almost 4,000 miles in each direction, its scattered territories 
occupying five different time zones, though the Japanese imposed Tokyo time throughout the captured lands for all formal purposes." ${ }^{1}$ An initial objective of this advance was to secure resources for the independence of Japan, but with such a large area the transportation of these natural resources became an issue.

Transportation in the form of the merchant marine became a critical factor in this new expanded empire. To defend such a large area the Japanese needed to have naval forces in place to react to any threats. This required bases to support these naval forces along with all the support personnel and supplies required. Troops to defend these bases and newly acquired territory required food, supplies, and other war material to remain effective. Beyond the military needs of these new areas their whole economic system had just undergone a radical change. These countries had just lost many of their traditional trading partners. Japan now needed to fill the role of the former colonial powers by buying resources and also providing finished goods for the many empty markets of the former colonies. For all of these strategic purposes Japan needed a strong merchant marine, but the Japanese merchant marine was actually one of Japan's greatest weaknesses. "By the start of the Pacific War Japan had developed the world's third largest merchant fleet totaling over six million tons and consisting of 700 ocean-going freighters, 132 passenger-cargo vessels and 49 ocean-going tankers. Despite this apparently impressive total which reflected a steady expansion in merchant shipbuilding in the 1930s, the fleet could still only carry 65 per cent of Japan's peacetime imports by the time the southern offensive was launched." 2 To further compound the problem, the merchant marine shipping tonnage available to meet all the transportation needs was divided between three different groups. Some of the fleet was taken by the navy for its use and some by the army and the rest was left under civilian control. This disunified command structure was not the most effective. In addition to a poor command structure, convoy systems were not introduced until 1943, allowing allied submarines to stalk Japanese merchant marine shipping at will. By May 1942 Japan had captured an area containing all the raw materials needed for the war effort, but the merchant marine tonnage to transport these materials was insufficient to meet the needs of the Japanese home industries alone without even considered the need to support the military aspects of defending such a large space. "In 1940 Japan had imported three million tons of iron ore from the colonial Philippines and Malaya; by 1942 when occupying these territories, the merchant marine managed to transport only 100,000 tons of iron ore back to the homeland. By 1943, the dwindling merchant fleet, under incessant attack from air and sea, was being replaced by wooden ships, vulnerable and very slow." 3 This untenable situation at first left empty markets in many newly "liberated" countries and soon forced the Japanese to seek new solutions which often came at the expense of the newly "liberated" people themselves.

This quick victory is held by many to be common knowledge, however, the story of the impact on the native peoples is lacking. Turning the clock back to the beginning of the war I will look at the Japanese victories both military and diplomatic in the following three countries: Philippines, Burma, and Thailand. All of these countries have been the setting for movies about the Second World War and all of these movies have created their reality. First, however it is important to look at the historical perception of the events within these three countries at the beginning of the war.

\footnotetext{
${ }^{1}$ Kinvig 17

2 Kinvig 17

3 Kinvig 18
} 


\section{The Philippines}

The Philippines was a newly independent country at the beginning of the Second World War, however, there was still a large United States military presence in the country. The military commander of this group was General Macarthur. "A genuine hero of World War I, he had been the head of the U.S. Army during the 1930s and had accepted the job of leading the infant Philippine Army (which brought with it the title field marshal) partially because the Japanese threat was recognized and everyone felt safer with someone of his caliber in charge out there."4 Macarthur had to retired from the U.S. Army to become field marshal of the Philippines military, but with the heightened tensions of the prewar years, Macarthur rejoined the United States army and was placed in command of all the forces in the Philippines. In late 1941, Macarthur had a large force under his command including 25,000 U.S. and Philippine regular troops and over 100,000 Philippine conscript soldiers. ${ }^{5} \mathrm{He}$ also had the largest concentration of the new B-17 bombers outside of the continental United States which was supposed to act as a strategic deterrent to the Japanese. The Japanese were not deterred and on 7 December 1941 they attacked Pearl Harbor.

Macarthur's response to the attack on Pearl Harbor was slow. He did not use his B-17 bomber force as planned to strike the Japanese mainland and this resulted in his air force being destroyed on the ground. He was also slow in responded with his ground forces to the invasion of the Philippines by Japanese ground forces. War Plan Orange called for a systematic withdrawal to the Bataan peninsular which had favorable defensive terrain, but Macarthur formulated his own response. "When the Japanese invaded, Macarthur, rather than implement the long-standing operational plan, which called for an immediate withdrawal to the rugged Bataan peninsula, decided to try to halt the Japanese in mobile operations on the North Luzon Plain. The results were disastrous." 6 After realizing that his mobile defense was losing ground quickly Macarthur agreed to a withdrawal, but by this time the Japanese advance had been so swift as to not allow the allied forces to gather supplies such as food and ammunition to the area near Bataan to withstand a long siege.

There has been much discussion of the defeat of eth United States military forces in the Philippines, but a more recent debate has arisen concerning the motivations of General Macarthur. With the retreat to Bataan the Japanese marched into the capital, Manila and the Philippine government was evacuated to the island of Corregidor. At this same time the Philippine government "authorized the transfer to the general and his closest aides of $\$ 640,000$ from the Philippine Treasury."7 Simple accepting the money was against army regulations and many historians have questioned Macarthur's motivations. "The recipients, as serving officers of the U.S. Army, were forbidden by regulations to accept a substantial loan or gift or emolument from a person or firm with whom it is the officer's duty as an agent of the government to carry out negotiations." 8 While Macarthur had money transferred to him the Japanese completed their conquest of the Philippines. From their bases in Formosa the Japanese army and navy air forces dominated the airspace over the Philippines and then the Navy encircled the country. The Japanese Army landed with 50,000 troops and conquered the country in just five months.

\footnotetext{
4 Dunnigan and Nofi, 17

5 Dunnigan and Nofi, 16

6 Dunnigan and Nofi 16

${ }^{7}$ Costello 269

${ }^{8}$ Costello 269
} 
The Philippines fell and Macarthur was evacuated to Australia. Historians today discuss the possible reasons for Macarthur's payment, but there is little discussion of the impact of a poor country spending such a large amount of money which may have been used to help rebuild after the war.

In April of 1943MGM released the movie Bataan based on the fall of the Philippines. "Bataan is the story of a group of hastily assembled volunteers who, through their bravery and tenacity, hold off an overwhelmingly large group of the enemy long enough to buy important time for the American forces." 9 These men come from varied backgrounds and show a united group standing against a strong enemy. The intention of this movie is to motivate the nation for war and present the message that the United States must stand together. "Alone deep in the jungle, a handful of Americans stand guard-a west pointer, a working class sergeant, an air force officer, a Latino, a black, a young sailor, and two Filipinos." 10 Several problems exist in the image provided by this movie. The army was segregated, but blacks and white are shown serving together. In addition despite the fact that the troops of the Philippines outnumbered American troops by over four to one, there are only two Pilipino soldiers in the group. This movie creates its own perception of the battle for the Philippines which helps to hide the casualties of the native people of the Philippines.

\section{Thailand}

Thailand was the only country in Southeast Asia to avoid becoming a colony and was only able to do this by careful diplomacy. This diplomacy included a careful balance of play between the French in Indochina and the British in Burma along with some territorial concessions. By the beginning of the hostilities in Asia a new alterative in the form Japan became available to the Thai government. At first the requests to allow Japanese troops through Thailand were declined, but Japan landed some troops in Thailand and the Thai government quickly signed an agreement with the Japanese which allowed the movement and stationing of the Japanese military in the country. This quick agreement did allow Thailand to officially remain a sovereign state, but the true nature of this sovereignty was questionable. Japan had given Thailand options in the agreement it signed with the incentive of returning land given to colonial powers earlier, but Thailand wanted to try to make an agreement which would require it to commit to the least amount of military support. Even with this agreement, however, in January 1942 Thailand declared war on the Allies. The movie Bridge on the River Kwai is based on events which occurred in Thailand by these events are closely linked with the fall of Burma so first I will discuss the situation in Burma before looking closely at the film.

\section{Burma}

With its troops now stationed in Thailand Japan saw the opportunity to make a move and hurt several of its enemies. An invasion of Burma form Thailand would push the British back into India, remove a large supplier of food to India upsetting the already delicate political situation there, and intersect the Burma road which was used by the united states to supply the Chinese national forces which had been fighting the Japanese since the mid-1930's. The control of Burma would also bring the Burmese natural resources under Japanese control, but more importantly provide the furthest line of defense for the newly acquired areas. Burma contained some very difficult terrain and the key to controlling Burma was control of Rangoon. To defend Burma the British only had two divisions: one Indian division which was supplied for desert warfare and a native Burmese division with very little training. The British military in Burma

\footnotetext{
9 Basinger 51

10 Koppes and Black 257
} 
tried a delaying action to slow the Japanese advance, but this only weakened their own forces. With experienced troops from the campaigns in Malaya, the Japanese were able to rapidly advance and surround Rangoon. Only but retreating north instead of west were the British able to avoid being trapped in the city, but once separated from Rangoon the British had lost their main line of communication and a long 900 mile retreat from Rangoon followed. "Rangoon was the key to Burma, and once the Japanese had taken the city the whole country was unlocked." 11 The Japanese did make some attempts to show that they were liberating a fellow Asian nation from a European imperialist including placing Burmese in positions which were once held by British colonial bureaucrats. Burma, however, was not granted independence and remained under strict Japanese military control. An anti-colonial military group did emerge known as the Burma Independence Army or BIA. This group was pro-Japanese and moved behind the advancing Japanese forces. Rather than a true military force the BIA was a source of violence along racial lines against groups such as Indian workers in Burma.

With the Japanese victory in Burma the question became how to make it a true defensive line to protect the resource rich areas from the allied forces in India. Burma was on the far end of a vast new empire and in a very difficult position to resupply by sea. Merchant shipping needed to travel around the long Malaysian peninsular to provide the needed supplies especially war material to defend against the allied forces in India and to keep the overland supply line to china interdicted. To help alleviate the shortage in merchant shipping tonnage the Japanese commandeered all Burmese vessels and ordered construction of wooden vessels, but even with these efforts were not enough. Large amounts of merchant ships were lost in the effort to keep supplies flowing to Rangoon so alternate measures were explored. During the invasion of Burma, Japanese troops had crossed over from Thailand through an area which included very difficult mountain and jungle terrain. There were not any all weather roads or a rail line but the distance was very short compared to the distance by sea. "The distance from Bangkok to Rangoon by sea is a little less than 2,000 miles; overland it would be about 350 ." 12 With a critical shortage of merchant marine vessels the Japanese decided to build a rail line from Bangkok to Rangoon to ship resources and supplies. This Burma-Thai railroad would also be known as the death railway and became a well known episode in the history of the Second World War for the cruelty to allied prisoners of war. It is less know for cost in Thai, Indian, and Burmese lives which far exceeded the commonly referenced cost in military lives.

\section{THE BURMA-THAI RAILWAY AND THE BURMA ROAD}

The conflict in Southeast Asia became centered on the problem of supply. The armies of the United States, Britain and Japan which fought in the area were far removed form their home countries and bases of supply. Conditions in the area such as disease, climate, and terrain all further increased the need for supply and it is in this context that the battle should be examined. The Americas, the British and the Japanese all tried to tackle the supply problem by putting large amounts of resources into creating supply routes. The resources in question were often native populations.

For the United States the priority was to maintain the flow supplies to Chinese forces. Towards this end the United States military created a land route known as the Burma Road. This "artery through the mountains had been completed as recently as 1938 by a labour force of 200,000 coolies. It linked Kunming, the provincial capital of mountainous Yunnan with Lashio in Burma, 350 miles to the south west; there it joined the Burmese road system running down to

\footnotetext{
11 Kinvig 22

12 Kinvig 23
} 
Rangoon."13 This link was soon severed with the Japanese control of Burma and the United States was soon forced to attempt to resupply the Chinese by air. "Before the ultimate test of battle could ever occur, each side had to attempt to solve immense logistical problems to get their forces to the battlefield and to keep them supplied there, for Burma was a uniquely isolated land. The Japanese Burma-Siam railway was one attempt at a solution; the British and United States' high commands each undertook a similar major logistical enterprise to surmount the problems which this aspect of the land battle presented for them. The United States had little intrinsic interest in Burma as a theatre of war and even less in returning it to the imperial ownership of the British; for them it provided the last landward lifeline to the beleaguered Chinese."14 The Burma Road was not reopened until 1945 when the outcome of the war was already decided. "During the next ten months it carried only 38,000 tons of materiel into Yunnan, compared with the 39,000 tons flown in each month by the huge US airlift to China over the mountains of the 'Hump Route'."15

The road the British army attempted to build faced different problems than the one completed by the American military. The British did not have as much engineering equipment as the Americans did and more importantly the area where they were building the road did not any stone supply appropriate for building a road. The British responded by building eth road out of brick, but this forced them to ship in materials from India and then construct small plants to produce the brinks often along the roadway.

In contrast to the two road projects undertaken by the allied armies, the Japanese attempted to build a railway to address the problem of supply. Japan's sea power was not adequate to reinforcing the Burma frontier the only option was a railway. The most important aspect of the railway was to link Bangkok and Rangoon. This connection would give the Japanese good internal lines of communication and a means to rapidly redeploy forces if needed. A road was considered, but in the rainy season conditions of some of the roads did not allow them to be used effectively. The Japanese were short of motor vehicles, but did have railroad engines and supply available in the area further reinforcing the decision to build a rail line rather than a road.

The railway would require massive amounts labor to complete and the situation in Burma was ideal to help with this condition. Since Japan had conquered Burma the usual trade patterns had been disrupted. Burma had always produced large amounts of rice, but her usual customer's were not an open market for Burmese rice. "India was Burma's chief rice buyer and together with Britain, the rest of Europe and Ceylon it took 85-90 per cent of Burma's overall export trade." 16 This forced lots of farmers to leave their traditional line of occupation and move to the cities to seek work. With an available work force mostly in Rangoon, the Japanese military approached local Burmese leaders. According to the Burmese authorities the argument use by the Japanese to elicit help from them "gave me a glimpse of the Asian future we were fighting for. The railway would also wipe out the 'deep historical wrong' according to which the European colonial powers had kept Burma and Thailand separated in order to preserve imperial spheres of influence."17 The argument worked and with the help of local Burmese rulers the Japanese were able to recruit large numbers of native laborers to work on the railroad project.

\footnotetext{
13 Kinvig 19

${ }^{14}$ Kinvig, preface xvi

15 Kinvig, preface xvii

16 Kinvig 36

17 Kinvig 37
} 
Efforts were also made in Thailand to recruit workers as this was the other country the railway would cross. These efforts took the form of negotiations because officially Thailand was still a sovereign nation. "Negotiations were necessary and a series of conferences was held in Bangkok between Thai government representatives, Thai National Railways and the Japanese authorities in the person of Major General Shimoda, in charge of $2^{\text {nd }}$ Railway Control of the Japanese Southern Army." 18 The final agreement reached provided the land for the Japanese to build the railway. Thailand also agreed to take some of the burden for building the southern section of the railroad. Even with the cooperation of local governments the Japanese military committed a large number of resources to the building of the rail link between Bangkok and Rangoon.

In addition to the two railway regiments, each of four battalions and totaling roughly 5,000 men, there was the Material Workshop of about 1,000 men with its main strength at Nong Pladuk and the remainder at the Burma terminus, Thanbyuzayat. The Nong Pladuk workshop was reputed to be the best-equipped in South East Asia. There were also special bridging units, a signals unit, a labour unit and, of course, a number of attached civilian specialist engineers. Supporting them were medical hygiene units, a water supply unit, a field hospital and a commissariat. The total Japanese involvement in the enterprise amounted to about 13,000 men. Many of the officers in the railway regiments were specialist railway or construction engineers and, together with the civilian engineers serving with them, they certainly had the expertise and the experience to undertake the project. ${ }^{19}$

Due to the rugged nation of the terrain to be traversed manual labor was required on a large scale. Even with Burma and Thailand helping with the recruitment of native laborers and the large commitment of Japanese military resources more manual labor was needed to complete the railway.

\section{PRISONER TREATMENT}

Even with the cooperation of the Thai and Burmese governments the recruitment effort was not enough to gather the amount of manual labor required. A lot of manual labor was supplied by native Indians in Burma, but with the occupation by Japan and the actions of the BIA many Indians fled back to their home country of India. Other sources of labor were soon discovered. "In 1942 however the labour problem was already solved; in camps throughout the region the Japanese had more prisoners of war than they knew what to do with" 20 allied prisoner's of war would be used to help construct the railway.

This has become one of the more well known episodes of the war in South East Asia due to the large number of deaths resulting from mistreatment. A comparison with POW's in Europe shows a vast difference in the rates of casualties. "Of the American and British prisoners of war captured by Germany and Italy, 4 percent died; but 27 percent of American and British POW's died at the hands of the Japanese." 21

One advantage held by native laborers on the railway over the allied prisoners of war was the option to desert which many utilized. That was about their only advantage as the military

\footnotetext{
18 Kinvig 38

19 Kinvig 45

20 Kinvig 25

${ }^{21}$ Koppes and Black 253
} 
training and organizational structure of the prisoners of war helped them deal with their situation better than the native laborers could on their own.

Desertion was not an option for the thousands of prisoners of war who were now working on the line. Although they suffered from the disadvantage of being entirely in the power of the Japanese, their military organization, social discipline and medical services helped them to survive the ordeal by labour that their lives were becoming. They had a rudimentary but efficient camp organization which attempted to ensure that the basic facilities would be available for the workers when they returned from their long day's labour on the line. Cookhouses were set up, stoves and ovens were improvised from a variety of sources, cooking pots were fashioned, water carriers were manufactured, a water supply was arranged, anti-malaria parties were set up, sick bays and camp hospitals were established and the prisoner camp commandants through whom the Japanese conducted the operations did there best to appease their captors and, at the same time, to protect their men from excessive toil, harsh punishment and sickness. ${ }^{22}$

Even with these advantages the commonly held popular culture image of the Burma-Thai railway is on the terrible ordeal of the allied prisoners of war ignoring the hidden casualties of the native populations.

Even within the allied nations the weight of the story is shifted. The number of prisoners has an inverse relationship with the amount of coverage given the event in official histories. "The Australian and New Zealand official histories accord the prisoners' story a more prominent place. New Zealand, with about 9,000 of its nationals taken prisoner during the Second World War, devoted an entire volume of its official history to their story; Australia, with 22,000 captured by the Japanese alone, recounted their treatment in 170 pages; Britain, with 136,000 prisoners in Japanese hands had only ten pages in the five volumes of The War Against Japan recording their not uneventful incarceration." ${ }^{23}$ Even with the unexpected relationship the focus is still firmly placed on the allied POWs.

As harsh as the treatment of prisoners of war on the railway was and in contrast to the popular cultural image as the Burma-Thai railway being the ultimate example of cruelty there are much more extreme examples of mistreatment. Sandakan was a large POW camp. "By September 1943 Sandakan POW camp held about 2,000 Australian POW's and 500 British POW's; only 6 survived to the end of the war - a survival rate of 0.24 percent. At Ambon POW camp 123 out of a total of 528 Australian POW's survived; in this case the survival rate was 23 percent. A total of 60,500 POW's worked on the construction of the Burma-Thailand railroad; about 12,000 died a survival rate of more than 80 percent." 24 Much of this mistreatment has been placed on the individual guards, but an interesting aspect of the popular image of Japanese cruelty is that many of the guards were not Japanese.

The Japanese military used large number so Korean and Formosan conscripts to guard prisoners of war. "By having Koreans and Formosans guard white prisoners under Japanese command, the Japanese military hoped that the old 'pecking order' would be reversed - that non-Japanese Asians would come to see whites as inferior, subjugated people and the Japanese

\footnotetext{
22 Kinvig 64

${ }^{23}$ Kinvig, preface xv

24 Tanaka 11
} 
as the 'natural' leaders of Asia.." 25 Having these groups act as prison guards also freed up Japanese manpower to serve in frontline units and were thus a great benefit to the Japanese military, but their treatment was poor. Korean soldiers were required to speak Japanese, use Japanese names, and were often the victims of harsh punishment by Japanese superiors. "They were trained as de facto Japanese soldiers, yet their rank of kanshi-hei (guard) was lower than that of a private, and there was no possibility of promotion. Clearly the Korean guards...were treated as second-class soldiers within the forces, bound by the same iron discipline yet enjoying none of the prestige accorded to Japanese soldiers." 26 With little hope of changing their situation many of these guards were caught in an extremely difficult no-win situation. They were seen as captors by the prisoners they guarded and less than equals by the Japanese military. "The frustration of the guards became more intense as the war went on, and it was inevitable that they would turn that frustration on the POW's, the only people over whom they had any power."27 This aspect of the Burma-Thai railway shows another hidden casualty. While not in as bad of a situation as native laborers or even the allied prisoners of war many Koreans and Formosans were caught in a very difficult situation which is not often reflected in the popular cultural image of the conflict.

\section{The Bridge on the River Kwai}

\section{REFLECTIONS IN FILM}

Perhaps one of the strongest portrayals of the popular cultural image of the conflict is the film The Bridge on the River Kwai directed by David Lean. It was based on a book by Pierre Boulle and released in 1960 and continues to this day to be extremely popular. "The Bridge on the River Kwai has proved one of the most durable of the films to come out of the Second World War, still attracting a television audience of seven and a half million at its eighth BBC showing in Britain in March 1990 and retailing for a fresh generation of viewers its quite misleading account of railway bridge-building episode." 28 This movie as well has in it sown way created its own reality concerning the events surrounding the building of the bridge by allied POWs.

Many people today can quickly recall the reference to the movie when they hear the 'Colonel Bogey' refrain, but within the movie there are several factors which do not coincide with the historical events. These events as told by the story can be instantly recalled like the 'Colonel Bogey' refrain, but are in fact in error. "Few of the prisoners who worked on the Tamarkan Bridge would have recognized their commanding officer in Alec Guinness's Colonel Nicholson; while the bridge itself was destroyed not by commandos as the film would have us believe but, as many prisoners knew to their cost, by B-24 Liberators flying down from eastern India on long haul interdiction missions."29

"It is noteworthy that the prisoners of war who laboured on the railway were not the only ones who found its portrayal unrealistic; the Japanese took particular exception to it as well, but for quite different reasons."30 The Japanese complained that the film showed the Japanese lacking the skill to build the bridge when in fact their engineers were in charge of the project. Many of the Japanese engineers had trained in British universities before the start of the war. ${ }^{31}$ Both the

\footnotetext{
25 Tanaka 38

26 Tanaka 39

27 Tanaka 40

28 Kinvig, preface xii

${ }^{29}$ Kinvig, preface xii

${ }^{30}$ Kinvig, preface xiii

31 Kinvig 46
} 
allied and Japanese criticism of the movie fails to mention the lack of discussion of the impact of the railway on the lives of many native populations.

\section{Objective Burma}

In 1945, Warner Brothers released Objective Burma with Errol Flynn. As in the two films previously discussed, this film as well attempts to create its own reality. The film is about a group of American paratroopers who go behind Japanese lines in Burma to destroy an enemy radar station. Burma was, however, a British operation so again reality is shifted to fit the needs of the movie maker which in this case was to make people hate the Japanese. At one point in the film the paratroopers find and other group of paratroopers that they had separated from earlier. The group is found not only dead but mutilated leading to a controversial speech by one of the members of the party. "I thought I'd seen or read about everything one man can do to another, from the torture chambers of the middle ages to the gang wars and lynchings of today. But this-this is different. This was done in cold blood by people who claim to be civilized. Civilized! They're degenerate, immoral idiots. Stinking little savages. Wipe them out, I say. Wipe them off the face of the earth. Wipe them off the face of the earth." 32 In the original screenplay the speech had a slightly differently twist where Errol Flynn's character would state "There's nothing especially Japanese about this...You'll find it wherever you find fascists. There are even people who call themselves American who'd do it too." 33 This response did not make it into the movie, but it is another example of a controversy over the image projected in a movie. Both images in the controversy are a construct ignoring the hidden casualties of the native population of Burma. It is more important to present an image of combat in the pacific no matter how unrealistic the image is. This newly constructed image of the Pacific was reflected against a more commonly held image of what war was expected to be like in Europe. "The Pacific war, by contrast, took place in the wilderness, much of it a particularly frightening wilderness: the jungle." 34 Popular culture created its own reality within this jungle.

\section{HIDDEN CASUALTIES}

Not just in films, but even in the discussion of events surrounding the conflict in Southeast Asia at the beginning of the Second World War the image constructed seems to be very selective. Discussions of the conflict in the Philippines often centers on the heroic American defenders or if critical, on the controversial actions of Macarthur as the war began. But by far one of the greatest producers of a popular cultural image of the war which has transferred to historical reality for many is the Burma-Thai railway. While some estimates place the casualty rate for allied POW's at close to 20 percent there is no discussion of the civilian casualty rate. "There is only brief mention in the Allied POW's accounts of the activity of that other great labour force on the railway, the huge number of civilian labourers recruited in Burma and Malaya and elsewhere in South East Asia; the 'coolie forces' as the prisoners called them." 35 One of the stars of the movie The Bridge on the River Kwai was an American, but Americans actually were present in extremely small numbers especially when compared with other allied nations. "British railway deaths amounted to 6,904; 2,815 Australians perished in Burma and Thailand; the total of Dutch dead was well in excess of 2,000 and the bodies of 337 US prisoners were repatriated at the end of the war." 36 The native laborers on the railway suffered both greater losses, in raw numbers and as a proportion of those employed, and the communities from which they came endured greater social dislocation, than was the case with their fellow

\footnotetext{
32 Koppes and Black 263

33 Koppes and Black 263

34 Koppes and Black 253

35 Kinvig, preface xiv

36 Kinvig 198
} 
workers from the Allied forces. "The official historian of the British military administration which took over after the Japanese surrender suggests a death ratio 'probably reaching three out of seven among those drafted from Burma', which would put the total at about 75,000."37 While the allied forces made plans to bring food and medical supplies to their troops in Japanese camps, the native people did not have such a rapid relief effort. They were often left on their own and returned to their homes under their own power if they were physically able to do so. Later the allied powers did make an effort to support native labor groups, but the initial efforts were centered on their own troops. The native populations of the Philippines, Thailand, and Burma were left on their own much as the popular cultural image of the Second World War in Southeast Asia has left them out of the story.

\section{BIBLIOGRAPHY}

Bataan. Videocassette. Dir. Tay Garnett. MGM., 1943

Basinger, Jeanine, The World War II Combat Film, Columbia University Press, 1986

Costello, John, Days of Infamy, New York: Pocket Books, 1994

Costello, John, The Pacific War 1941-1945, New York: Rawson,Wade, 1981

Dower, John W., Japan in War and Peace, New York: New Press, 1993

Dunnigan, James F. and Aber Nofi, Victory at Sea, New York: Qill, William Morrow, 1995

Kinvig, Clifford, River Kwai Railway, London: Barssey's, 1998

Koppes, Clayton R. and Gregory D. Black, Hollywood Goes to War, The Free Press, 1987

Tanaka, Yuki, Hidden Horrors, Boulder: Westview Press, 1996

The Bridge on the River Kwai. Videocassette. Dir. David Lean. Columbia., 1957

Objective Burma. Videocassette. Dir. Raoul Walsh. MGM., 1945

${ }^{37}$ Kinvig 200 